\title{
Identification of Eutypa lata by PCR-RFLP
}

\author{
P. E. Rolshausen, F. Trouillas, and W. D. Gubler, Department of Plant Pathology, University of California, Davis \\ 95616
}

\begin{abstract}
Rolshausen, P. E., Trouillas, F., and Gubler, W. D. 2004. Identification of Eutypa lata by PCRRFLP. Plant Dis. 88:925-929.

Eutypa lata is a vascular canker pathogen of woody plants commonly diagnosed by isolating the pathogen from infected tissue. Related fungi from the same family, the Diatrypaceae, also have been found in association with grapevine in Californian vineyards. An in situ polymerase chain reaction (PCR) method has been developed for detection of $E$. lata in infected wood tissue. However, our results indicate that this method also would amplify other Diatrypaceous fungi, which could potentially lead to an incorrect diagnosis. Therefore, we developed a PCRrestriction fragment length polymorphism (PCR-RFLP) assay. The internal transcribed spacer (ITS)1/5.8S/ITS2 ribosomal DNA region was amplified by PCR using universal primers, and RFLP patterns were determined after digestion with AluI. The restriction profiles obtained served to distinguish E. lata from wood trunk pathogens of grapevine (Phomopsis viticola, Botryodiplodia sp., Phaeoacremonium aleophilum, and Phaeomoniella chlamydospora), Diatrypaceous fungi (Diatrype sp., Diatrypella sp., Eutypella vitis, and Eutypa leptoplaca), and Cryptovalsa sp. found on dead wood of grapevine, and other Eutypa spp. (E. petrakii var. hederae, E. astroidea, E. crustata, and E. lejoplaca), with the exception of E. armeniacae, which we regard as a synonym for E. lata, and E. laevata, which has not been found on grapevine.
\end{abstract}

Additional keywords: vegetative compatibility groups

Eutypa lata (Pers.) Tul. \& C. Tul (=E. armeniacae Hansf. \& M. V. Carter) is a major pathogen of cultivated crops such as apricot and grapevine and has been found all over the world (3). It is responsible for significant economic damage to the wine industry in California $(22,25)$.

E. lata (Ascomycetes, Diatrypaceae) can be identified based on morphological features of the meiosporic stage on the dead wood of infected hosts $(3,15,24)$. For disease diagnosis, positive identification of $E$. lata often is based on the mitosporic stage isolated from infected wood on potato dextrose agar (PDA). On this medium, $E$. lata grows as a white cottony mycelium, which can produce conidia from conidiogenous cells aggregated into enclosed or open conidiomata (15).

Other fungi placed in members of Diatrypaceae are difficult to separate from each others based solely on morphological features of their mitosporic stage. Also, the biology and taxonomy of this group of fungi is not well known. Glawe and Rogers (15) found other fungal species in

Corresponding author: P. E. Rolshausen

E-mail: perolshausen@ucdavis.edu

This work was supported by the American Vineyard Foundation and the Viticulture Consortium.

Accepted for publication 13 April 2004.

Publication no. D-2004-0701-02R

(C) 2004 The American Phytopathological Society this family on dead or declining hosts, suggesting they may be somewhat pathogenic. Cryptosphaeria populina (Pers.) Sacc. (16) and Eutypella parasitica R. W. Davidson \& Lorentz (8) are the only species other than $E$. lata reported to be pathogenic on aspen and maple, respectively. Trouillas et al. (26) reported the presence of several Diatrypaceous fungi in Californian vineyards on dead wood (Eutypa lata, Diatrypella sp., Diatrype sp., Eutypella sp., and Cryptovalsa sp.) including a second Eutypa sp., Eutypa leptoplaca Rappaz (27). These findings suggest that such fungi could be isolated from wood cankers instead of or in concert with E. lata. Therefore, incorrect identification of the target pathogen could occur. study ${ }^{\mathrm{a}}$ fungal specimens listed in Table 2.
Other techniques currently available to identify E. lata include serology $(12,23)$, fatty acid analysis (11), and a polymerase chain reaction (PCR)-based method (19). However, neither fatty acid analysis nor serological methods are used extensively for disease diagnosis. Lecomte et al. (19) developed an in situ detection method by PCR using primers designed to specifically amplify $5.8 \mathrm{~S}$ ribosomal DNA of E. lata. However, the three primer pairs (Lata 1/Lata 2-1, Lata 1/Lata 2-2, and Lata 3/Lata 2-1) were not tested on other Diatrypaceous fungi. Given the potential for other fungi in this family to co-occur with $E$. lata in grape wood tissue $(26,27)$, the possible lack of specificity of these primers may render this in situ detection procedure inadequate for accurate detection of E. lata.

After testing the specificity primer pairs Lata $1 /$ Lata $2-1$, Lata $1 /$ Lata $2-2$, and Lata 3/Lata 2-1 designed by Lecomte et al. (19), our objective was to develop an alternative molecular method to quickly and reliably identify E. lata in culture and distinguish it from morphologically similar and taxonomically related fungi. For this purpose, we used a PCR-restriction fragment length polymorphism (PCR-RFLP) method, which has been used effectively for identification of other fungal pathogens $(10,17,21)$.

\section{MATERIAL AND METHODS}

Isolates of $\boldsymbol{E}$. lata. Over $30 \mathrm{E}$. lata isolates were collected over the years at the University of California, Davis (UC Davis) from several plant hosts, including tree hosts and cultivated crops, and from several geographic locations worldwide. A subsample of $11 \mathrm{E}$. lata isolates was presented for this study (Table 1). Isolates

Table 1. Designation, geographic origin, plant host, and source of 11 Eutypa lata isolates used in this

\begin{tabular}{lccc}
\hline E. lata isolate & Geographic origin & Plant host & Isolate source \\
\hline E30 & United States-California & Vitis vinifera & Canker \\
E31 & United States-California & V. vinifera & Canker \\
E38 & United States-California & V. vinifera & Canker \\
E454 & United States-California & Prunus armeniaca & Canker \\
E455 & United States-California & P. armeniaca & Canker \\
ESW & Switzerland & V. vinifera & Ascospore \\
CBS 208.87 & Switzerland & Tilia sp. & Culture \\
E201 & Australia & V. vinifera & Culture \\
D001 & Australia & P. armeniaca & Culture \\
MD1 & Italy & Unknown & Culture \\
8D & France & Unknown & Culture \\
\hline
\end{tabular}

${ }^{a}$ All 11 E. lata isolates were tested with the polymerase chain reaction (PCR) restriction fragment length polymorphism (RFLP) method. E. lata isolate CBS (Centraalbureau voor Schimmelcultures, Netherlands) 208.87 was used as the reference isolate for evaluating PCR primers Lata 1/Lata 2-1, Lata 1/Lata 2-2, and Lata 3/Lata 2-1 (19), and for comparison of RFLP banding patterns to other 
were cultured from cankers in wood (five isolates) or from fruiting bodies (one isolate) as described by Carter (4). Each isolate was cultured on water agar before transferring a single hyphal tip to PDA in order to obtain a pure culture. The remaining five isolates were received as pure cultures from France (Institut National de la Recherche Agronomique, Villenave d'Ornon), Italy (Instituto di Pathologia Vegetale, Milano), Australia (Waite Research Precinct, Adelaide), and the Netherlands Centraalbureau voor Schimmelcultures (CBS). All isolates were stored at $4^{\circ} \mathrm{C}$ in sterile water.

Other fungal isolates. Phomopsis viticola (Sacc.) Sacc., Botryodiplodia sp., Phaeoacremonium aleophilum W. Gams, Crous, M. J. Wingf. \& L. Mugnai, and Phaeomoniella chlamydospora W. Gams, Crous, M. J. Wingf. \& L. Mugnai (Table 2) were isolated on PDA medium from wood necrosis of diseased grapevines in California, and were identified by their mitosporic stages based on the keys of Barnett and Hunter (2) and Crous et al. (7). Meiosporic stages of Diatrypella spp., Cryptovalsa spp., and Diatrype spp. were collected from grapevine in different regions in California and were identified based on the keys of Rappaz (24) and Glawe and Rogers (15). A culture of Eutypella vitis was obtained from Michigan State University and identified by a BLAST search in the GenBank database (1) using the internal transcribed spacer (ITS) $1 / 5.8 \mathrm{~S} / \mathrm{ITS} 2$ region (E. vitis accession number AJ302466), because only the mitosporic stage was available for identification. Pure cultures of Eutypa armeniacae Hansf. \& M. V. Carter, E. laevata (Nitschke) Sacc., E. petrakii var. hederae Rappaz, E. astroidea (Fries:Fries) Rapcrustata (Fries:Fries) Saccardo, and $E$. leptoplaca were received from the CBS collection. paz, E. lejoplaca (Fries:Fries) Fuckel, E.

DNA extraction. Mycelium for DNA extraction was obtained by cutting an agar plug drawn from the edge of a growing culture and placing it on a sterile cellophane strip ( 3 by $3 \mathrm{~cm}$ ) overlaid on PDA. Petri plates were inoculated at room temperature for 5 days in the dark. Mycelium was scraped off the cellophane, and DNA was extracted as described by Cenis (6).

Evaluation of specific PCR primers. Primer pairs Lata $1 /$ Lata $2-1$, Lata $1 /$ Lata 2-2, and Lata 3/Lata 2-1 (19) were tested independently on crude DNA of Phomopsis viticola, Botryodiplodia sp., Phaeoacremonium aleophilum, Phaeomoniella chlamydospora, Cryptovalsa sp., Diatrype sp., Diatrypella sp., Eutypella vitis, Eutypa lata (CBS 208.87), E. armeniacae, E. laevata, E. petrakii var. hederae, E. astroidea, E. leptoplaca, E. crustata, and E. lejoplaca (Table 2). PCR assays were set up in the same conditions as described by Lecomte et al. (19) and were performed at least two times for each fungal isolate. PCR products were run on a $1 \times$ Tris-borate EDTA (TBE) $1 \%$ agarose gel (BMA, Rockland, ME), stained with ethidium bromide, and visualized under ultraviolet (UV) light.

Vegetative compatibility test. Isolates of E. lata (Table 1) were tested for vegetative compatibility in order to make sure they were not clones. Isolates were paired in all possible combinations on PDA for 2 weeks at room temperature in the dark. If formation of a barrage was observed, the isolates were placed in different vegetative compatibility groups (VCGs); whereas, if no barrage was observed, isolates were placed in the same VCG (13). Isolates also were paired with themselves as a positive control (i.e., no barrage).

Evaluation of PCR-RFLP method. The ITS1/5.8S/ITS4 region was amplified in a 50- $\mu$ l reaction using a Taq PCR Core Kit (Qiagen, Valencia, CA) containing 36 $\mu \mathrm{l}$ of distilled water (GIBCO, Invitrogen

Table 2. Designation, geographic origin, and plant host of fungal organisms used in this study ${ }^{\text {a }}$

\begin{tabular}{|c|c|c|c|}
\hline Fungal organism & Plant host & Geographic origin & Isolate number ${ }^{b}$ \\
\hline Phomopsis viticola & Vitis vinifera & United States-California & $\mathrm{P} 470$ \\
\hline Phaeoacremonium aleophilum & $V$. vinifera & United States-California & Pa61 \\
\hline Phaeomoniella chlamydospora & $V$. vinifera & United States-California & Pc44 \\
\hline Botryodiplodia sp. & $V$. vinifera & United States-California & B422 \\
\hline Cryptovalsa sp. & $V$. vinifera & United States-California & A001 \\
\hline Diatrypella sp..$^{\mathrm{c}}$ & $V$. vinifera & United States-California & DHb500 \\
\hline Eutypella vitis ${ }^{\mathrm{c}}$ & V. vinifera & United States—Michigan & ELM13 \\
\hline Diatrype $\mathrm{sp}^{\mathrm{c}}$ & $V$. vinifera & United States-California & DHb200 \\
\hline Eutypa armeniacae $^{\mathrm{c}}$ & V. vinifera & Italy & CBS 622.84 \\
\hline E. laevata $\mathrm{c}$ & Salix sp. & Switzerland & CBS 291.87 \\
\hline E. petrakii var. hederae $e^{\mathrm{c}}$ & Hedera helix & Switzerland & CBS 285.87 \\
\hline E. astroidea ${ }^{\mathrm{c}}$ & Fraxinus excelsior & Switzerland & CBS 292.87 \\
\hline E. leptoplaca ${ }^{\mathrm{c}}$ & Arundo donax & France & CBS 286.87 \\
\hline E. crustata $^{\mathrm{c}}$ & Ulmus sp. & France & CBS 210.87 \\
\hline E. lejoplaca ${ }^{\mathrm{c}}$ & Acer pseudoplatanus & Switzerland & CBS 248.87 \\
\hline
\end{tabular}

${ }^{a}$ DNA of each fungal organism was used for evaluating polymerase chain reaction (PCR) primers Lata 1/Lata 2-1, Lata 1/Lata 2-2, and Lata 3/Lata 2-1 (19), and PCR-restriction fragment length polymorphism method.

${ }^{\mathrm{b}}$ CBS = Centraalbureau voor Schimmelcultures, Netherlands.

${ }^{\mathrm{c}}$ Fungal organism taxonomically classified in the family Diatrypaceae (Ascomycetes).
Corporation, Scotland, UK), $5 \mu \mathrm{l}$ of $10 \times$ PCR buffer, $4 \mu \mathrm{l}$ of $\mathrm{MgCl}_{2}, 2 \mu \mathrm{l}$ of dNTPs, $1 \mu \mathrm{l}$ of ITS 1 and ITS4 primers (28), $0.25 \mu \mathrm{l}$ of Taq DNA polymerase, and $1 \mu$ of DNA extract per reaction. A negative control (no DNA) was included in the PCR. Samples were processed through 35 cycles of $94^{\circ} \mathrm{C}$ for $1 \mathrm{~min}, 60^{\circ} \mathrm{C}$ for $1 \mathrm{~min}$, and $72^{\circ} \mathrm{C}$ for 1 $\min 30 \mathrm{~s}$. PCR products were run on a $1 \times$ TBE $1 \%$ agarose gel, stained with ethidium bromide, and visualized under UV light. The ITS1/5.8S/ITS2 region was further digested in a 30- $\mu$ l reaction containing $2 \mu \mathrm{l}$ of restriction enzyme AluI (New England Biolabs, Beverly, MA), 25 $\mu \mathrm{l}$ of PCR product, and $3 \mu \mathrm{l}$ of $10 \times$ enzyme buffer. The restriction digestion profile was run on a $1.5 \%$ agarose gel, stained with ethidium bromide, and visualized under UV light. The PCR-RFLP method was performed at least two times for each fungal isolate listed in Tables 1 and 2.

\section{RESULTS}

No PCR products were obtained with primer pairs Lata $1 /$ Lata $2-1$, Lata $1 /$ Lata 2-2, and Lata 3/Lata 2-1 designed by Lecomte et al. (19) when tested with Phomopsis viticola, Botryodiplodia sp., Phaeoacremonium aleophilum, and Phaeomoniella chlamydospora. However, amplicons of the expected size were obtained with all three primer pairs when tested with a Cryptovalsa sp., Diatrype sp., Diatrypella sp., Eutypella vitis, Eutypa lata, and E. leptoplaca (Fig. 1). Moreover, PCR products also were obtained with all three primer pairs when tested on E. armeniacae, E. laevata, E. petrakii var. hederae, E. astroidea, E. crustata, and E. lejoplaca (data not shown).

Eleven isolates of $E$. lata were tested in all combinations and found to be all vegetatively incompatible, indicating that no clone was represented more than once in our sample. Digestion of the PCR-amplified ITS1/5.8S/ITS2 region with AluI yielded three bands of approximately 0.3 , 0.2 , and $0.1 \mathrm{~kb}$ for all isolates of E. lata (Fig. 2). To confirm our findings with the initial group of isolates, both vegetative compatibility tests and PCR-RFLP assays also were applied to the entire collection of E. lata isolates established at UC Davis. Isolates always were placed in different VCGs and intraspecific polymorphism was never detected among them (data not shown).

The PCR-RFLP method also was tested with other fungal pathogens found in association with grapevine $(18,26,27)$. Restriction profiles of Phomopsis viticola, Botryodiplodia sp., Phaeoacremonium aleophilum, and Phaeomoniella chlamydospora clearly were different from that of E. lata (Fig. 3). Different banding patterns also could separate $E$. lata from a Diatrype sp., Diatrypella sp., Eutypella vitis, and Cryptovalsa sp. (Fig. 4). However, Diatrype sp. and Diatrypella sp. shared the 
same banding patterns, as did Eutypella vitis and Cryptovalsa sp. Within the genus Eutypa, no separation could be made between Eutypa lata, E. armeniacae, and $E$. laevata. Likewise, E. astroidea, E. leptoplaca, and E. crustata shared a common banding pattern (Fig. 5). The restriction profiles of these two groups were different from each other and also from E. lejoplaca and E. petrakii var. hederae.

\section{DISCUSSION}

The taxonomic disposition of fungi within the family Diatrypaceae remains unclear and somewhat artificial. Also, the biology of these organisms is poorly understood. Many species in this family are found on dead hosts (15). Trouillas et al. (26) identified several fungi (Diatrype sp., Diatrypella sp., Cryptovalsa sp., and Eutypella vitis) on dead wood of grapevine in addition to the pathogen Eutypa lata, including another Eutypa sp., E. leptoplaca (27). E. lata is being recognized as the main pathogen responsible for grapevine dieback, but the frequency of occurrence of other Diatrypaceous fungi in woody tissue of grapevine and their pathogenic abilities have not been determined yet.

Lecomte et al. (19) developed an identification method of $E$. lata by PCR directly from infected wood tissue. The design of their primer pairs from the ITS region was based on one E. lata isolate. The BLAST search for specificity of their designed primers showed no match with other Diatrypaceous fungi, because this group was not represented in the GenBank database at the time. Nucleotide sequences of several species of diatryapceous fungi have been deposited in the GenBank database since, and evidence of the lack of specificity of primer pairs Lata $1 /$ Lata $2-1$, Lata $1 /$ Lata 2-2, and Lata 3/Lata 2-1 now can be demonstrated by BLAST search (1). We further demonstrated the lack of specificity of all three primer pairs by performing PCR on several fungal isolates. No PCR products were obtained from fungi that are found in dead grapevine wood but are taxonomically distinct from E. lata, such as Phomopsis viticola, Botryodiplodia sp., Phaeoacremonium aleophilum, and Phaeomoniella chlamydospora (18), which confirmed the results obtained by Lecomte et al. (19). However, a lack of specificity of all three primer pairs was demonstrated with taxonomically related Diatrypaceous fungi and a Cryptovalsa sp. Given the potential for these fungi to inhabit grape wood tissue, the in situ PCR detection method may be inadequate for positive detection of E. lata. Lecomte et al. (19) also developed three other primer pairs (SCA 10A/SCA 10B, SCB 02A/SCB 02B, and $\mathrm{SCD} 18 \mathrm{~A} / \mathrm{SCD} 18 \mathrm{~B}$ ) from random amplified polymorphic (RAPD) DNA fragments that were not tested in the present study. These primers may be more suitable for detection and diagnosis of
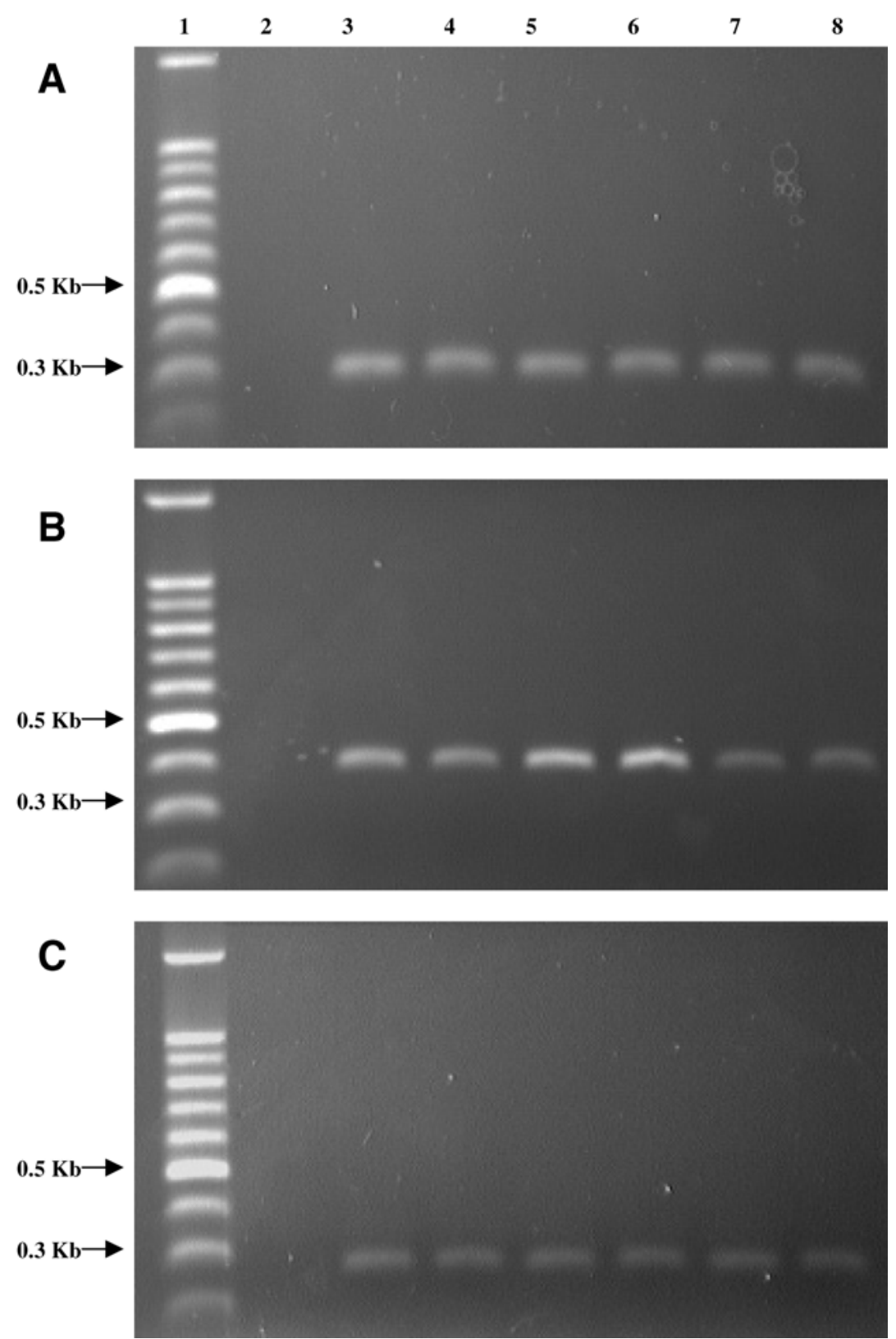

Fig. 1. Polymerase chain reaction (PCR) amplification of the internal transcribed spacer (ITS)1/5.8S/ITS2 region using primer pair A, Lata 1/Lata 2-1, B, Lata 1/Lata 2-2, and C, Lata 3/Lata 2-1 from DNA of five Diatrypaceous fungi and a Cryptovalsa sp. found in their meiosporic stages on dead wood of grapevine in California. The PCR products were run on a $1 \times$ Tris-borate EDTA $1 \%$ agarose gel, stained with ethidium bromide, and checked under UV light. Lane 1, 1-kb ladder; lane 2, negative control (no DNA); lane 3, Eutypa lata (CBS 208.87); lane 4, E. leptoplaca (CBS 210.87); lane 5, Diatrype sp. (DHb200); lane 6, Diatrypella sp. (DHb500); lane 7, Eutypella vitis (ELM13); lane 8, Cryptovalsa sp. (A001).

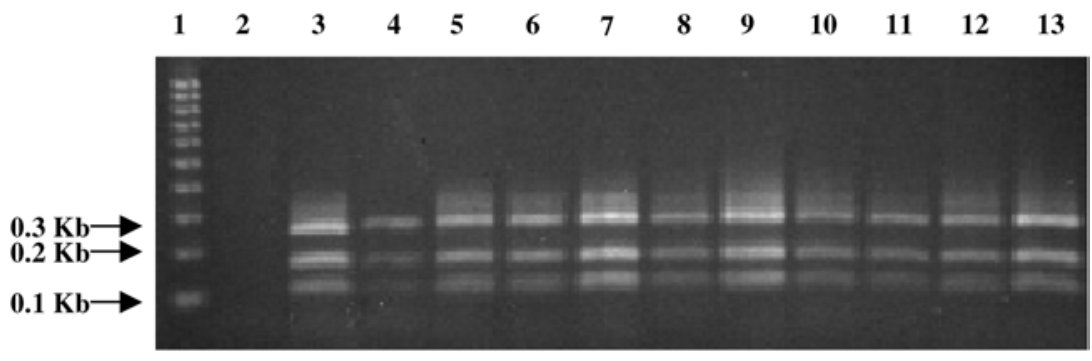

Fig. 2. Restriction fragment length polymorphism patterns of the polymerase chain reaction (PCR)-amplified internal transcribed spacer (ITS)1/5.8S/ITS2 region using universal primer pair ITS1/ITS4 digested with restriction enzyme AluI, from DNA of 11 Eutypa lata isolates. Digested PCR products were run on a $1 \times$ Trisborate EDTA $1.5 \%$ agarose gel, stained with ethidium bromide, and checked under UV light. Lane 1, 1 -kb ladder; lane 2, negative control (no DNA); lane 3, E30; lane 4, E31; lane 5, E38; lane 6, MD1; lane 7, 8D; lane 8, ESW; lane 9, CBS 208.87; lane 10, E201; lane 11, D001; lane 12, E454; lane 13, E455. 


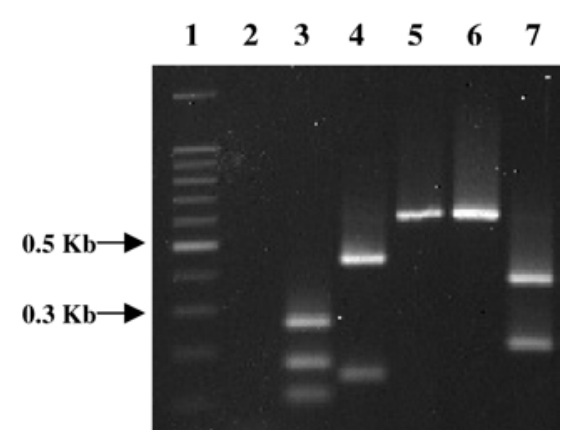

Fig. 3. Restriction fragment length polymorphism patterns of the polymerase chain reaction (PCR)amplified internal transcribed spacer (ITS)1/5.8S/ITS2 region using universal primer pair ITS1/ITS4 digested with restriction enzyme $A l u \mathrm{I}$, from DNA of fungi isolated from wood necrosis of grapevine. Digested PCR products were run on a $1 \times$ Tris-borate EDTA $1.5 \%$ agarose gel, stained with ethidium bromide, and checked under UV light. Lane 1, 1-kb ladder; lane 2, negative control (no DNA); lane 3, Eutypa lata (CBS 208.87); lane 4, Phomopsis viticola (P470); lane 5, Phaeoacremonium aleophilum (Pa61); lane 6, Phaeomoniella chlamydospora (Pc44); lane 7, Botryodiplodia sp. (B422).

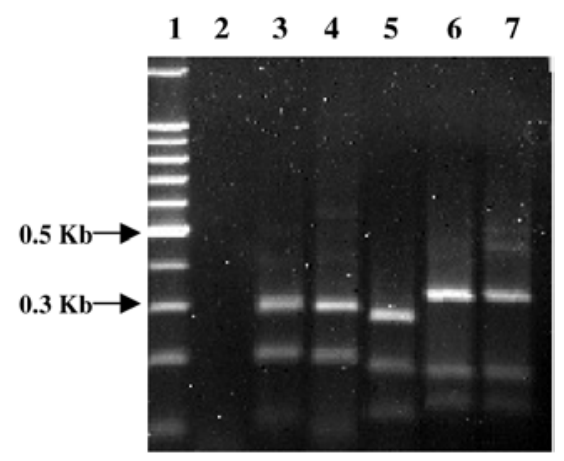

Fig. 4. Restriction fragment length polymorphism patterns of the polymerase chain reaction (PCR)-amplified internal transcribed spacer (ITS)1/5.8S/ITS2 region using universal primer pair ITS1/ITS4 digested with restriction enzyme AluI, from DNA of five fungal genera found in their meiosporic stage on dead wood of grapevines. Digested PCR products were run on a $1 \times$ Tris-borate EDTA 1.5\% agarose gel, stained with ethidium bromide, and checked under UV light. Lane 1, 1-kb Ladder; lane 2, negative control (no DNA); lane 3, Eutypella vitis (ELM13); lane 4, Cryptovalsa sp. (A001); lane 5, Eutypa lata (CBS 208.87); lane 6, Diatrype sp. (DHb200); lane 7, Diatrypella sp. (DHb500).

E. lata because of the increased specificity they have to offer versus primers designed from the ribosomal DNA region. However, Lecomte et al. (19) found the RAPD primers to be less sensitive than primers designed from the ITS region for detection of $E$. lata directly from infected wood because of the high copy number of ribosomal DNA targeted by the primer pairs Lata 1/Lata 2-1, Lata 1/Lata 2-2, and Lata 3/Lata 2-1 in comparison to the RAPD primer pairs.

The PCR-RFLP method developed in this study was specific enough to identify

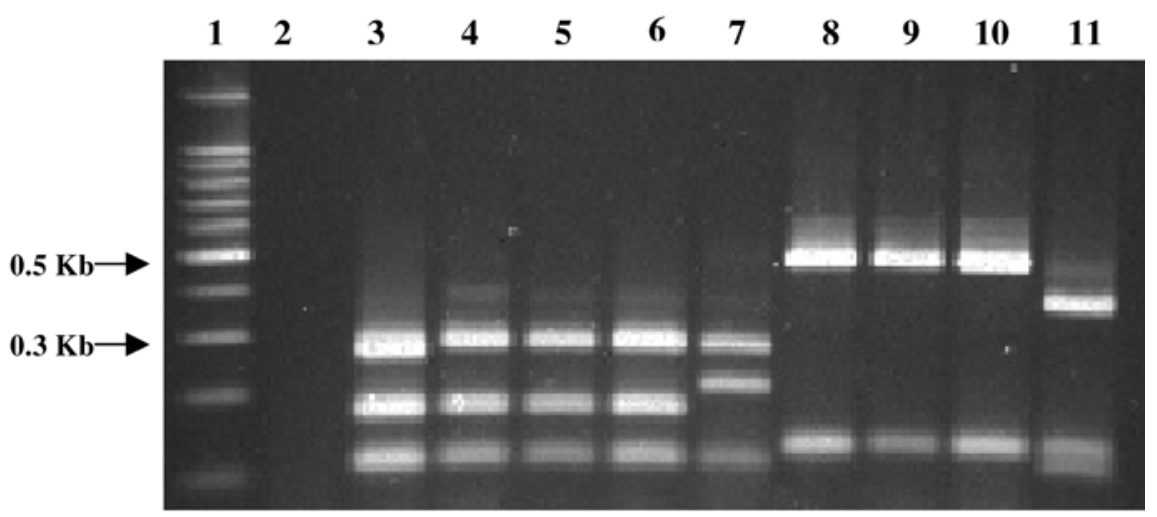

Fig. 5. Restriction fragment length polymorphism patterns of the polymerase chain reaction (PCR)amplified internal transcribed spacer (ITS) 1/5.8S/ITS2 region using universal primer pair ITS1/ITS4 digested with restriction enzyme AluI, from DNA of several Eutypa spp. Digested PCR products were run on a $1 \times$ Tris-borate EDTA $1.5 \%$ agarose gel, stained with ethidium bromide, and checked under UV light. Lane 1, 1-kb ladder; lane 2, negative control (no DNA); lane 3, Eutypa lata (CBS 208.87); lane 4 E. lata (E31); lane 5, E. armeniacae (CBS 622.84); lane 6, E. laevata (CBS 291.87); lane 7, E. petrakii var. hederae (CBS 285.87); lane 8, E. astroidea (CBS 292.87); lane 9, E. leptoplaca (CBS 286.87); lane 10, E. crustata (CBS 201.87); lane 11, E. lejoplaca (CBS 248.87).

E. lata from wood trunk pathogenic fungi found in association with grapevine dieback (18), and from other genera in the family Diatrypaceae found on dead wood of grapevine $(26,27)$ as well as several other Eutypa spp. However, no polymorphisms distinguished E. lata from $E$. armeniacae or E. laevata. E. laevata was identified only on Salix sp. (24) and, therefore, is not likely to be confused with $E$. lata during isolation from grapevine. $E$. armeniacae was described originally on Prunus armeniaca (3) and is responsible for branch dieback. E. armeniacae was reported to be morphologically identical to E. lata (14). These species are regarded as synonymous by some authors (24) but are separated by others $(9,20)$. The PCR-RFLP method was not tested directly in situ for identification of $E$. lata, because the use of universal primers ITS1/ITS4 for PCR (1) would potentially amplify the ITS1/ 5.8S/ITS2 region of several fungi inhabiting wood tissue, resulting in multiple PCR products. Therefore, recognition of $E$. lata by RFLP pattern could not be achieved after digestion by AluI. Thus, the PCRRFLP method requires fungi to be cultured for identification purposes.

In summary, the PCR-RFLP assay we have developed appears to be a reliable method for identification of the causal agent of Eutypa dieback. The utility of this method is based on the assumption that $E$. laevata is not found on grapevine and that $E$. armeniacae is truly synonymous with $E$. lata. This method proved to be more specific than the PCR detection method developed by Lecomte et al. (19) when using primer pairs Lata 1/Lata 2-1, Lata 1/Lata 2-2, and Lata 3/Lata 2-1, although it cannot be applied directly in situ. The PCRRFLP method potentially could be used for diagnosis on other cultivated crops on which E. lata has been reported to be pathogenic $(3,5)$. Considerable research is yet needed to clarify the taxonomy and the biology of the family Diatrypaceae in order to achieve more effective management of the diseases caused by this group of fungi.

\section{ACKNOWLEDGMENTS}

We thank P. Larignon (INRA, Villenave D'Ornon, France), P. Cortesi (Instituto Di Pathologia Vegetale, Milano, Italy), M. Grease (Waite Research Precinct, Adelaide, Australia), S. Butterworth (Michigan State University), M. V. Carter (Australia), and A. Bolay (Switzerland) for providing fungal isolates used in this study; and $\mathrm{T}$. Gordon and D. Rizzo (Department of Plant Pathology, UC Davis) for providing advice on the writing of this manuscript.

\section{LITERATURE CITED}

1. Altschul, S. F., Madden, T. L., Schäffer, A. A., Zhang, J., Zhang, Z., Miller, W., and Lipman, D. J. 1997. Gapped BLAST and PSI-BLAST: a new generation of protein database search programs. Nucleic Acids Res. 25:3389-3402.

2. Barnett, H. L., and Hunter, B. B. 1987. Illustrated Genera of Imperfect Fungi. 4th ed. MacMillan, New York.

3. Carter, M. V. 1957. Eutypa armeniacae Hansf. \& Carter, sp. nov., an airborne vascular pathogen of Prunus armeniaca L. in Southern Australia. Aust. J. Bot. 5:21-35.

4. Carter M. V. 1991. The status of Eutypa lata as a pathogen. Monogr. Phytopathol. Pap. No. 32 International Mycological Institute, Surrey, UK.

5. Carter, M. V., Bolay, A., and Rappaz, F. 1983. An annotated list and bibliography of Eutypa armeniacae. Rev. Plant Pathol. 62:251-258.

6. Cenis, J. L. 1992. Rapid extraction of fungal DNA for PCR amplification. Nucleic Acids Res. 20:2380.

7. Crous, P. W., Gams, W., Wingfield, M. J., and Van Wyk, P. S. 1996. Phaeoacremonium gen. nov. associated with wilt and decline diseases of woody hosts and human infections. Mycologia 88:786-796.

8. Davidson, R. W., and Lorenz, R. C. 1938 Species of Eutypella and Schizoxylon associated with cankers of maple. Phytopathology 28:733-749.

9. DeScenzo, R. A., Engel, S. R., Gomez, G., Jackson, E. L., Munkvold, G. P., Weller, J., and Irelan, N. A. 1999. Genetic analysis of Eutypa strains from California supports the presence of two pathogenic species. Phytopathology 89:884-893. 
10. Edel, V., Steinberg, C., Gautheron, N., and Labouvette, C. 1996. Evaluation of restriction analysis of polymerase chain reaction (PCR)amplified ribosomal DNA for the identification of Fusarium species. Mycol. Res. 101:179187.

11. Ferreira, J. H. S., and Augustyn, O. P. H. 1989. Differentiation between Eutypa lata and Cryptovalsa ampelina by means of Cellular Fatty Acid Analysis. S. Afr. J. Enol. Vitic. 10:18-22.

12. Francki, R. I. B., and Carter, M. V. 1970. The serological properties of Eutypa armeniacae mycelium and ascospores. Aust. J. Biol. Sci. 23:713-716.

13. Glass, N. L., and Kuldau, G. A. 1992. Mating type and vegetative compatibility in filamentous Ascomycetes. Annu. Rev. Phytopathol. 30:201-224.

14. Glawe, D. A., and Rogers, J. D. 1982. Observations on the anamorphs of six species of Eutypa and Eutypella. Mycotaxon 14:334-346.

15. Glawe, D. A., and Rogers, J. D. 1984. Diatrypaceae in the Pacific Northwest. Mycotaxon 20:401-460.

16. Hinds, T. E. 1981. Cryptosphaeria canker and
Libertella decay of aspen. Phytopathology 71:1137-1145.

17. Kim, S. H., Han, A., Kronstad, J., and Breuil, C. 1999. Differentiation of sapstain fungi by restriction length polymorphism patterns in nuclear small subunit ribosomal DNA. FEMS Microbiol. Lett. 177:151-157.

18. Larignon, P., and Dubos, B. 1997. Fungi associated with esca disease in grapevine. Eur. J. Plant Pathol. 103:147-157.

19. Lecomte, P., Peros, J.-P., Blancard, D., Bastien, N., and Delye, C. 2000. PCR assays that identify the grapevine dieback fungus Eutypa lata. Appl. Environ. Microbiol. 66:4475-4480

20. McKemy, J. M., Glawe, D. A., and Munkvold, G. P. 1993. A hyphomycetous synanamorph of Eutypa armeniacae in artificial culture. Mycologia 85:941-944

21. Moleleki, N., Preisig, O., Wingfield, M. J., Crous, P. M., and Wingfield, B. D. 2002. PCRRFLP and sequence data delineate three $D i$ aporthe species associated with stone and pome fruit trees in South Africa. Eur. J. Plant Pathol. 108:909-912.

22. Munkvold, G. P., Duthie, J. A., and Marois, J.
J. 1994. Reductions in yield and vegetative growth of grapevines due to Eutypa dieback. Phytopathology 84:186-192

23. Price, T. V. 1973. Serological identification of Eutypa armeniacae. Aust. J. Biol. Sci. 26:389394.

24. Rappaz, F. 1987. Taxonomie et nomenclature des Diatrypacees a asques octosporees. Mycol. Helv. 2:285-648.

25. Siebert, J. B. 2001. Eutypa: the economic toll on vineyards. Wines Vines April 50-56.

26. Trouillas, F. P., Rolshausen, P. E., and Gubler, W. D. 2001. Importance of Eutypa lata and occurrence of other Diatrypaceous fungi in Northern Californian vineyards. (Abstr.) Phytopathology 91:S89.

27. Trouillas, F. P., Rolshausen, P. E., and Gubler, W. D. 2003. Discovery of a second Eutypa species pathogenic to grapevine in California. (Abstr.) Phytopathology 93:S130.

28. White, T. J, Bruns, T, Lee, S., and Taylor, J. 1990. Amplification and direct sequencing of fungi ribosomal RNA genes for phylogenetics. Pages 315:322 in: PCR Protocols. A Guide to Methods and Applications. Academic Press, San Diego, CA. 